\title{
Is Adolescent Body Weight Associated With Parental Beliefs About Overweight, Attitudes Towards Food, and the Home Environment?
}

\author{
Dörthe Krömker ${ }^{1}$, Andreas Stolberg ${ }^{2}$, Claudia Müller ${ }^{3}$, Zhe Tian $^{1} \&$ Alexandr Parlesak ${ }^{4}$ \\ ${ }^{1}$ McGill University, Clinical and Health Informatics Research Group, Montréal, Canada \\ ${ }^{2}$ University of Applied Sciences Fresenius, Idstein, Germany \\ ${ }^{3}$ Zurich University of Applied Sciences, Wädenswil, Switzerland \\ ${ }^{4}$ Metropolitan University College, Global Nutrition and Health, Copenhagen, Denmark \\ Correspondence: Dörthe Krömker, McGill University, Clinical and Health Informatics Research Group, \\ Montréal, Canada. E-mail: doerthe.kroemker@mcgill.ca
}

\author{
Received: November 23, 2014 Accepted: January 6, 2015 Online Published: January 21, 2015 \\ doi:10.5539/jfr.v4n2p104 \\ URL: http://dx.doi.org/10.5539/jfr.v4n2p104
}

\begin{abstract}
Parents play a crucial role in the development of childhood overweight and also in controling overweight. This study investigated a broad set of parental factors, including general attitudes towards food (price, identity, cooking, ecology, mood, dieting, convenience, functionality), social cognitions concerning overweight (risk perception, self-efficacy for exercising and healthy eating, response efficacy for exercising and healthy eating) and characteristics of the home environment (restriction of snacks, regular family meals, parents involved in sports) and their association with their children's zBMI, i.e. adolescents between 12-19 years old. In a non-clinical sample of 842 parent-adolescent dyads we found that the zBMI is most strongly and positively associated with parental dieting attitudes and negatively with parents' self-efficacy to motivate their children to exercise. The zBMI is negatively and weakly associated with dislike of cooking, identification with the way of eating and the perceived benefit of healthy eating (response efficacy). Half of the parents assessed their children's overweight and obesity correctly, while the other half underestimated it. No difference was found with respect to all investigated variables (general attitudes, social cognitions concerning overweight and home environment) between parents who correctly perceive and those who misperceive their children's weight status.
\end{abstract}

Keywords: dieting, feeding practices, food choice motives, health beliefs, risk perception, restraint eating, social cognitions

\section{Introduction}

Childhood and adolescent overweight and obesity are considered major causes of grave health problems such as type 2 diabetes and cardiovascular disease (Daniels et al., 2005; Kaufman, 2002). The rapid growth of obesity over the last few decades has alarmed health professionals worldwide (WHO, 2012) and makes it urgent to understand the driving factors for these developments.

Although genetic factors influence body weight, the current prevalence of childhood overweight and obesity is influenced by a variety of other individual and social factors (Lowe, 2003; Ogden, Yanovski, Carroll, \& Flegal, 2007). Parents are likely to shape children's home environment with regard to eating and exercising behaviors, thereby facilitating or preventing weight gain. In fact, weight loss programs are more effective when parents were included or even exclusively targeted with change measures (Epstein, Valoski, Wing, \& McCurley, 1994; Golan \& Crow, 2004). Given the importance of parents as change agents in weight control (Golan, 2006), it has been the aim of this study to investigate a large set of parental factors and their association with children's weight status.

Therefore the study expands on previous research by evaluating a broad range of parents' attitudes towards food and nutrition, beliefs about consequences of overweight, healthy eating and exercising and the concrete shaping of the home environment. Specifically, three groups of parental factors were studied: 1) characteristics of the home environment, 2) parents' beliefs concerning overweight and 3) parents' general attitudes towards food and nutrition. With respect to the characteristics of the home environment (1), we assumed that restricted access to snacks in the household is associated with higher weight status, whereas regular family meals and the importance 
of sports in the family are associated with lower weight. Concerning the beliefs about overweight (2), we assumed, based on the Health Belief Model (Becker, Maiman, Kirscht, Haefner, \& Drachman, 1977; Janz \& Becker, 1984) that parents' lower perception of overweight as a health threat (risk perception), their lack of confidence in being able to motivate children to eat healthily and to exercise (self-efficacy), and a weaker belief that healthy eating and exercising are suitable strategies to manage weight (response efficacy) is associated with higher children's weight. Additionally, we investigated whether parents perceive the weight status of their child correctly. Finally, with respect to general attitudes (3), we explored how a broad range of parents' attitudes towards food, particularly price, convenience, functionality (foods that contain potentially health-enhancing additives such as vitamins or minerals), mood, dieting, ecology, and cooking is related to their children's weight.

\subsection{Background}

Home environment: Previous research has found that parental feeding practices aimed at restricting a child's access to snack food were associated with higher weight status (Clark, Goyder, Bissell, Blank, \& Peters, 2007; Faith, Scanlon, Birch, Francis, \& Sherry, 2004; Fisher \& Birch, 1999). On the other hand, shared family meals seem to promote healthy eating and contribute to a normal body weight (Berge, Jin, Hannan, \& Neumark-Sztainer, 2013; Fruh, Fulkerson, Mulekar, Kendrick, \& Clanton, 2011; Larson, Neumark-Sztainer, Hannan, \& Story, 2007; Wansink \& Van Kleef, 2014). General parenting styles, such as authoritative or permissive, might affect specific feeding practices and the children's body mass (Sleddens, Gerards, Thijs, De Vries, \& Kremers, 2011). Furthermore, parents play an important role with respect to their children's physical activity. Adolescents proved to be more physically active when supported by their parents (Lloyd, Lubans, Plotnikoff, Collins, \& Morgan, 2014; Sallis, Prochaska, \& Taylor, 2000). Little is known, however, about whether parents' pleasure in exercising themselves is related to their children's level of exercise and body weight Parents' attitude to sports and their own level of physical activity might function as a positive role model or establish a sports culture in the household.

Parents' beliefs: In contrast to these specific food- or exercise-related parenting practices, little is known about the beliefs parents hold about overweight as a health risk and their capacity to influence their children's weight-related behavior (Gerards, Hummel, Dagnelie, de Vries, \& Kremers, 2013). Behavioral health theories, which consider perceived risk and other psychological variables, have been applied to weight-related health behaviors for adults and adolescents (O'Connell, Price, Roberts, Jurs, \& McKinley, 1985; Park, 2011). These studies have shown that the perception of overweight as a health risk, the belief that healthy eating and exercising helps to reduce weight (response efficacy), and the confidence to be able to effect the necessary health behaviors (self-efficacy) are positively associated with exercising (Hausenblas, Carron, \& Mack, 1997; Plotnikoff, Costigan, Karunamuni, \& Lubans, 2013; Sullivan et al., 2008) and healthy eating (Bebetsos, Chroni, \& Theodorakis, 2002; Conner, Norman, \& Bell, 2002; Fila \& Smith, 2006; Hewitt \& Stephens, 2007). It is an open question though, how parents' beliefs concerning these issues are related to their children's weight status. Only a few studies have investigated these variables and they focused mainly on self-efficacy. These studies support the assumption that parents' self-efficacy is associated with children's weight related behavior, such as exercising (Adkins, Sherwood, Story, \& Davis, 2004; Smith et al., 2010; Taveras, Mitchell, \& Gortmaker, 2009). With respect to risk perception it might be important to consider whether parents evaluate their children's weight status correctly in the first place. Research showed that between $50-80 \%$ of parents of overweight or obese children underestimate their children's weight status (Aljunaibi, Abdulle, \& Nagelkerke, 2013; Etelson, Brand, Patrick, \& Shirali, 2003; Hudson, McGloin, \& McConnon, 2012; Lim \& Wang, 2013; Lundahl, Kidwell, \& Nelson, 2014). This misperception might hinder parents to take appropriate measures to ameliorate weight status and to prevent potential health problems associated with overweight. Perception of overweight was most often studied in relation to socio-demographic factors, showing that younger age, gender and various ethnic backgrounds were associated with underestimation of overweight (De La O et al., 2009; Eckstein et al., 2006; Towns \& D'Auria, 2009). Little is known about whether or not there are any differences with respect to food and health-related beliefs between parents who perceive their children's weight status correctly or those who underestimate it.

General attitudes: What people eat is, however, not only influenced by health-related thinking. General attitudes towards food with respect to such variables as price, ethics, convenience, identity, or mood are also related to peoples' food choices (Bisogni, Connors, Devine, \& Sobal, 2002; Devine, Sobal, Bisogni, \& Connors, 1999; Grunert, 2002; Lindeman \& Sirelius, 2001). Only a few studies have thus far investigated parents' general attitudes towards food. Research suggests taking these general factors into account because food preferences, especially for healthy food such as fruits and vegetables, seem to be passed on from parents, but not from peers (Guidetti, Conner, Prestwich, \& Cavazza, 2012). On top of that, parents' attitudes not only towards healthy food, 
but also towards convenience and ethics, were shown to be associated with their children's food consumption (Roos, Lehto, \& Ray, 2012).

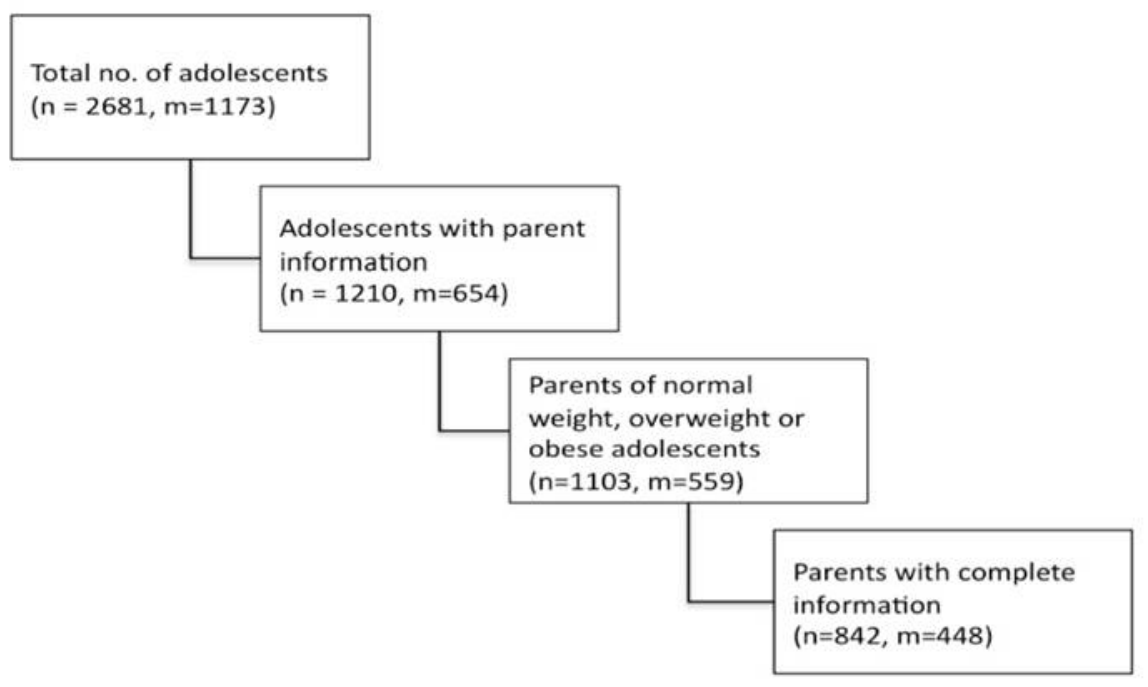

Figure 1. Inclusion criteria for adolescent-parent dyads considered in this study

Note: $\mathrm{N}=$ total sample of adolescents, $\mathrm{m}=$ random subsample of total adolescent sample for whom weight and height was measured by trained research assistants.

\section{Methods}

\subsection{Participants}

A cross-sectional study was done in the framework of a large survey about nutrition, exercise and health in Germany with school students (Krömker \& Vogler, 2011; Müller, Roscher, Parlesak, \& Bode, 2011). Students from grades 7-10 were recruited from a random sample of 89 schools stratified by school type (integrated school, basic school, middle school and higher education school "Gymnasium") and geographic location (urban and rural areas). In total, 2,681 adolescents aged 12 to 19 years from five different provinces (Länder) and 1,210 parents were surveyed. Excluding the underweight students, and those for whom parent data were not complete, data from 842 parent-adolescent dyads are presented in this paper (s. Figure 1).

\subsection{Procedure}

Ethical approval and consent for the study was given by each provincial and local school authority (Provincial Ministries of Schools and each individual school). Only adolescents who presented informed consent of their parents to participate were included in the study. Adolescents filled in the questionnaire during a school session provided for this purpose. Additionally, from a randomly picked sub-sample of $\mathrm{N}=1173$ students, drawn from the total student sample, trained research assistants measured height and weight with a stadiometer and digital scale. For the sample of parent-adolescent dyads presented in this paper, objectively measured data are available for 53\% ( $\mathrm{N}=448)$ of all students (Figure 1). Parents were not informed about the body weight status of their children. All parents were invited to fill in the parent questionnaire at home and to send it back to the school or the research offices, which was done by $45 \%(\mathrm{~N}=1210)$ of all parents.

\subsection{Measures}

A standardized questionnaire was developed for the purposes of this study. It was pretested with a think-aloud method (Brickenkamp, 1997) and in a different sample with parents of preschool children. The questionnaire included sections about eating and nutrition, exercising, the child's health status and development as well as socio-demographics. Agreement/disagreement to the statements provided was evaluated on a 6-point Likert scale ranging from 1 - does not apply at all to 6 - does apply totally. Examples and variables used are presented in Table 2. Based on a national life style study, which identified general food types (Hayn \& Schultz, 2004), and on the Food Choice Questionnaire (Steptoe, Pollard, \& Wardle, 1995) the parents' general attitudes towards food and nutrition were measured with 21 items. We identified the following dimensions: price, indicating a preference for inexpensive foods; convenience, indicating a preference for pre-prepared instead of home-made 
meals; functionality, indicating a preference for foods that contain potentially health-enhancing additives such as vitamins or minerals; mood, indicating that eating is used to regulate stress; dieting, indicating a preference for calorie-reduced foods and paying attention to avoid "fattening foods"; ecology, indicating a preference for organically grown food; identity, indicating that participants feel that they express their identity, i.e. "who they are" with the way they eat; and cooking, indicating that cooking is not liked and perceived as unpleasant.

Based on social cognitive theories, several statements were used to evaluate the perceived health risk from overweight (e.g. 3 statements assessed for risk); regarding nutrition, 5 statements were used to assess self-efficacy and barriers such as child does not like healthy food; and 3 statements were used to assess beliefs about the efficacy to manage weight by eating fruits and vegetables (response efficacy). With respect to exercising, 4 statements were used to assess self-efficacy and barriers such as child prefers media usage and does not like exercising and 5 statements were used to assess beliefs about the efficacy to manage weight by exercising (response efficacy). One question assessed whether parents thought that their child "was much too thin, a little too thin, just about right, a little too heavy or much too heavy". Finally, with respect to the home environment, 7 statements were used to investigate whether, and in which way (alone, any time or together) meals occurred in the household, what rules existed around meals (TV on or conversation time) and whether access to sweets and snacks was restricted. Seven (7) statements were used to assess how important sports and exercising were for parents and for the whole family.

Parents' marital status, income, education and occupation were also assessed. Since questions concerning household income often remained unanswered, the household's socio-economic status was assessed based on the parents' occupations, which reflects education and income (Ganzeboom \& Treiman, 2003; Hoffmeyer-Zlotnik \& Geis, 2003). Therefore, all occupations were classified by trained coders according to the International Standard Classification of Occupations (ISCO-88) and subsequently classified according to the "Standard International Occupational Prestige Scale" (SIOPS) (Ganzeboom, De Graaf, \& Treiman, 1992; Ganzeboom \& Treiman, 1996), which takes social prestige attached to a specific occupation into account (Geis, 2007). Both partners' occupational prestige in a household was compared and the higher prestige level was used to determine the family occupational prestige.

Parents' Body Mass Index (BMI) was calculated based on self-reported height and weight using the formula of weight $(\mathrm{kg}) /$ height $(\mathrm{m})^{2}$. Weight status of adolescents was calculated based on measured height and weight data when available and otherwise on self-reported data. National reference values for age and sex specific BMI distributions (Kromeyer-Hauschild et al., 2001) were used to calculate the Box-Cox-transformed z-score of the BMI (zBMI) according to Cole and colleagues (Cole, Bellizzi, Flegal, \& Dietz, 2000):

$$
\left.\mathrm{Z}=\left[\left((\mathrm{BMI} / \mathrm{M})^{\wedge} \mathrm{L}\right)-1\right] /(\mathrm{S} * \mathrm{~L})\right) \text {. }
$$

Therefore the national value references were used to identify the age- and sex-specific BMI median (M), skewness (L) and coefficient of variation (S). This standardized zBMI allows direct comparison of the weight status of girls and boys of different ages within one sample because the age and sex specific weight distributions are corrected. Otherwise subgroups would need to be built and then compared.

\subsection{Data Analysis}

The data were analyzed for outliers, normality, missing values, and linearity. Principal Component Analysis (PCA) with orthogonal rotation was used in order to reduce multicollinearity and to build independent and reliable variables for the food attitudes, the parents' beliefs and home environmental factors (Tabachnik \& Fidell, 2001). Inter-item reliability was calculated using Cronbach's alpha. Items as identified by PCA were integrated into one predictor by calculating the mean. Multiple linear regression was used to analyze the association between parental factors and adolescent zBMI with alpha level set to 0.05 . Adolescent sex and age, as well as parental weight status and the household social prestige (SIOPS) value were included as confounders. Additionally, using t-tests, differences with respect to all parental factors were analyzed between parents who perceived the weight status of their child correctly and incorrectly. Applying Bonferroni correction due to multiple hypotheses testing, alpha level was set to 0.002. In the group of overweight and obese children the parents' assessment was classified as correct if the overweight child was perceived as a "little too heavy" and if the obese child was perceived as "much too heavy". Other perceptions were classified as "incorrect". Data were processed and analyzed using SPSS Statistics software, version 20.0, and R software, version 3.0.1.

\section{Results}

Table 1 presents the study sample with respect to demographics and weight status. The Pearson correlation between objectively measured and self-reported body weight for the cohort of adolescents is very high $(\mathrm{r}=0.92$; 
$\mathrm{p}=0.000 ; \mathrm{N}=1164$ ) and indicates that the self-reported data can be considered as a reliable measurement for the adolescent weight status. Using a two sampled chi-squared test, no significant difference in the distribution of weight status was found between those adolescents for whom parental data were available and those for whom parental data were not available. Using the same test, a small statistically significant difference was found with respect to social prestige (SIOPS), indicating that more parents with a higher social status answered the questionnaire; however, the difference of 1.3 on the SIOPS scale (ranging from 0-100) is deemed too small to be of social relevance. Table 2 presents the means, standard deviations and Pearson correlations with the adolescent zBMI of all variables included in the regression analysis. Reliability and an exemplary statement are presented for factors that were produced as a result of the PCA. No satisfactory reliability $(<0.59)$ could be observed for "restriction", "response efficacy for healthy eating", or "functional food (general food attitude)" and therefore the single items that loaded most strongly on the respective factors were included in the regression analysis.

Table 1. Socio-demographic characteristics and weight status of the sample.

\begin{tabular}{|c|c|c|}
\hline Variable Name & Mean (SD) & $\mathrm{N}(\%)$ \\
\hline Socio-economic prestige (SIOPS) of family & $46.3(12.37)$ & \\
\hline \multicolumn{3}{|l|}{ Marital Status Parents: } \\
\hline - Both parents living together & & $853(78.9 \%)$ \\
\hline - Other & & $227(21.1 \%)$ \\
\hline Mother's BMI & $24.5(4.42)$ & \\
\hline - Underweight $(\mathrm{BMI}<18.5)$ & & $16(1.5 \%)$ \\
\hline - Normal weight $(\mathrm{BMI}=18.5-24.9)$ & & $635(61.8 \%)$ \\
\hline - Overweight $(\mathrm{BMI}=25-29.9)$ & & $266(25.9 \%)$ \\
\hline - $\quad$ Obese $(\mathrm{BMI}>=30)$ & & $110(10.7 \%)$ \\
\hline Father's BMI & $26.5(3.49)$ & \\
\hline - Underweight $(\mathrm{BMI}<18.5)$ & & $5(0.5 \%)$ \\
\hline - Normal weight $(\mathrm{BMI}=18.5-24.9)$ & & $307(33.1 \%)$ \\
\hline - Overweight $(\mathrm{BMI}=25-29.9)$ & & $482(52.0 \%)$ \\
\hline - $\quad$ Obese $(\mathrm{BMI}>=30)$ & & $132(14.2 \%)$ \\
\hline \multicolumn{3}{|l|}{ Adolescent's BMI: } \\
\hline - Normal weight (5. - 84. Percentile zBMI) & & $891(83.4 \%)$ \\
\hline - Overweight (85. - 94. Percentile zBMI) & & $121(11.3 \%)$ \\
\hline - Obese $(>=95$. Percentile zBMI) & & $56(5.2 \%)$ \\
\hline Adolescent Age & $14.8(1.10)$ & \\
\hline \multicolumn{3}{|l|}{ Adolescent Sex: } \\
\hline - Male & & $479(43.6 \%)$ \\
\hline - Female & & $619(56.3 \%)$ \\
\hline
\end{tabular}


Table 2. Descriptive statistics for variables considered in the multiple regression analysis.

\begin{tabular}{|c|c|c|c|}
\hline Variable name, parent factor & Mean & $\mathrm{SD}$ & $\begin{array}{l}\mathrm{r} \text { with } \\
\text { zBMI }\end{array}$ \\
\hline \multicolumn{4}{|l|}{ General Attitude towards Food: } \\
\hline $\begin{array}{l}\text { - Identity, } 3 \text { statements, } \alpha=.87 \text {, example: "The way we eat also expresses } \\
\text { who we are." }\end{array}$ & 3.38 & 1.37 & -0.09 \\
\hline $\begin{array}{l}\text { - Price, } 3 \text { statements, } \alpha=.75 \text {, example: "When buying groceries I always } \\
\text { look for the most inexpensive foods." }\end{array}$ & 3.13 & 1.09 & 0.11 \\
\hline $\begin{array}{l}\text { Dislike cooking, } 3 \text { statements, } \alpha=.70 \text {, example: "For me cooking is an } \\
\text { annoying duty" }\end{array}$ & 2.17 & 1.05 & -0.04 \\
\hline $\begin{array}{l}\text { - Organic, } 3 \text { statements, } \alpha=.71 \text {, example: "I try to buy as many organic } \\
\text { food items as possible." }\end{array}$ & 3.60 & 1.13 & -0.09 \\
\hline $\begin{array}{l}\text { - Diet, } 3 \text { statements, } \alpha=.65 \text {, example: "When buying groceries I always } \\
\text { look for calorie reduced foods." }\end{array}$ & 3.31 & 1.04 & 0.20 \\
\hline $\begin{array}{l}\text { - Convenience, } 3 \text { statements, } \alpha=.59 \text {, example: "I prefer convenience food } \\
\text { over home-made dishes." }\end{array}$ & 1.68 & 0.71 & 0.08 \\
\hline $\begin{array}{l}\text { - Mood, } 2 \text { statements, } r=.73 \text {, example: "When I am stressed, I can calm } \\
\text { down by eating." }\end{array}$ & 2.35 & 1.35 & 0.06 \\
\hline $\begin{array}{l}\text { - Functional, } 1 \text { statement: "I like foods with additives such as vitamins and } \\
\text { minerals." }\end{array}$ & 4.00 & 1.55 & 0.10 \\
\hline \multicolumn{4}{|l|}{ Home setting: } \\
\hline $\begin{array}{l}\text { Family meal, } 5 \text { statements, } \alpha=.74 \text {, example: "In our family, meals are an } \\
\text { important time to spend together." }\end{array}$ & 5.03 & 0.82 & -0.13 \\
\hline $\begin{array}{l}\text { - Restriction, } 1 \text { statement: "At our house everybody can take snacks and } \\
\text { sweets whenever they like." }\end{array}$ & 3.81 & 1.53 & -0.11 \\
\hline $\begin{array}{l}\text { - Importance of sports, } 7 \text { statements, } \alpha=.85 \text {, example: "In our family it is } \\
\text { very important to do sports regularly." }\end{array}$ & 4.21 & 1.02 & -0.16 \\
\hline \multicolumn{4}{|l|}{ Parental Beliefs: } \\
\hline $\begin{array}{l}\text { - Risk Perception of overweight as health problem, } 3 \text { statements, } \alpha=.72 \\
\text { example: "Overweight worsens the health of children and adolescents." }\end{array}$ & 5.49 & 0.74 & -0.10 \\
\hline $\begin{array}{l}\text { - Response efficacy exercising, } 5 \text { statements, } \alpha=.73 \text {, example: } \\
\text { "Exercising has no impact on the healthy development of my child } \\
\text { (inversed)." }\end{array}$ & 4.95 & 0.75 & -0.10 \\
\hline $\begin{array}{l}\text { - Self-efficacy exercising, } 4 \text { statements, } \alpha=.73 \text {, example: "In spite of } \\
\text { many obstacles, I am confident that I can persuade my son/daughter to } \\
\text { exercise." }\end{array}$ & 4.21 & 1.06 & -0.24 \\
\hline $\begin{array}{l}\text { - Self-efficacy healthy eating, } 5 \text { statements, } \alpha=.69 \text {, example: "In spite of } \\
\text { many obstacles I am confident that I can make my son/daughter eat a lot } \\
\text { of fruits and vegetables." }\end{array}$ & 4.51 & 0.81 & -0.11 \\
\hline $\begin{array}{l}\text { - Response efficacy healthy eating, } 1 \text { statement: "Children who eat a lot } \\
\text { fruits and vegetables don't become overweight." }\end{array}$ & 4.81 & 1.09 & -0.11 \\
\hline
\end{tabular}

Note: $\alpha$ : Cronbach's alpha, r: coefficient of correlation

\subsection{Parental Factors and Their Association With Adolescent Weight Status}

Multiple linear regression was used to identify those parental factors that were associated with the adolescent zBMI while controlling for the mother's and father's BMI, children's age and sex as well as social prestige of the family. Results of the final model, which depicts only the variables significantly associated with the zBMI are presented in Table 3. Collinearity statistics were in acceptable ranges with tolerance measures between 0.907 
and 0.992 as well as Variance Inflation Factor (VIF) not higher than 1.1. The adjusted R-squared statistic is 0.23 for the complete model and is 0.22 for the final model. Higher standardized beta values indicate a stronger correlative association with the dependent variable (zBMI) while controlling for all other considered variables. It showed that the adolescent zBMI is most strongly and positively associated with parental dieting attitudes and the mother's BMI and negatively with parents' self-efficacy to motivate their children to exercise. Further, the zBMI is associated with sex, with boys being heavier than girls. Two more general attitudes towards food and nutrition are negatively and weakly associated with the zBMI: the weight status is the higher the more parents like cooking (inversed) and the less they identify themselves with their way of eating. Weak associations are found between adolescent body weight and parental beliefs about both the benefits of healthy eating and exercising. Whereas the perceived benefit of healthy eating is negatively associated with the zBMI as hypothesized, the benefit of exercising is, on the contrary, positively associated with the zBMI. When each variable is analyzed univariately via Pearson correlation with zBMI, belief about exercise benefit showed a negative correlation (Table 2). However, due to the correlation and multicollinearity of this variable with the mother's BMI and self-efficacy exercising, we removed this variable from the analysis. The other parental factors associated with the zBMI and the variance accounted for then remained similar.

Table 3. Results of linear multiple regression with adolescent zBMI as dependent variable and final set of independent variables

\begin{tabular}{llllll}
\hline Variable name & $\beta$ & $\mathrm{B}$ & Lower 95\% & Upper 95\% & $\mathrm{P}$ \\
\hline General Food Attitude: Identity & -0.072 & -0.043 & -0.081 & -0.006 & 0.024 \\
General Food Attitude: Dislike cooking & -0.07 & -0.055 & -0.103 & -0.008 & 0.023 \\
General Food Attitude: Diet & 0.242 & 0.192 & 0.143 & 0.241 & $<0.001$ \\
Self-efficacy exercising & -0.219 & -0.174 & -0.222 & -0.125 & $<0.001$ \\
Response efficacy healthy eating & -0.071 & -0.054 & -0.101 & -0.007 & 0.024 \\
Male adolescent & 0.16 & 0.265 & 0.166 & 0.364 & $<0.001$ \\
BMI mother & 0.194 & 0.036 & 0.025 & 0.048 & $<0.001$ \\
BMI father & 0.086 & 0.02 & 0.006 & 0.035 & 0.007 \\
\hline
\end{tabular}

Note: Adjusted R-squared $=.22$.

\subsection{Correct and Incorrect Perception of Weight Status}

Table 4 indicates the actual weight status and the parents' perception of their children's weight status. For this analysis, we considered the parents of overweight or obese adolescents only. Half (50\%) of the parents under-estimate the weight status of their children, with $43.3 \%$ judging their overweight children as "about right" or too thin and $64.9 \%$ judging their obese child as "a little too heavy" or as "about right". With the necessary Bonferroni correction, no significant differences regarding the variables considered in this study were observed between the two parent groups.

Table 4. Parents' judgment of their children's weight status among overweight and obese adolescents

\begin{tabular}{lll}
\hline Parent judgment & \multicolumn{2}{l}{ Adolescent's weight status } \\
\hline & overweight N (\%) & obese N(\%) \\
much too thin & 0 & 0 \\
a little too thin & $1(0.8 \%)$ & 0 \\
about right & $51(42.5 \%)$ & $1(1.9 \%)$ \\
a little too heavy & $67(55.8 \%)$ & $34(63 \%)$ \\
much too heavy & $1(0.8 \%)$ & $19(35.2 \%)$ \\
Total: & 120 & 54
\end{tabular}

Note: *classified as "misperception", total $\mathrm{N}$ of misperception $=87$; total $\mathrm{N}$ of correct perception $=86$. 


\section{Discussion}

It was the purpose of this work to analyze a broad set of parental factors associated with their children's zBMI. General attitudes towards food and nutrition with respect to dieting, cooking, and identity as well as self-efficacy to motivate adolescents to exercise, and perceived benefits of healthy eating were significantly associated with the adolescents' zBMI when controlling for parental body weight, sex and social prestige. In considering general attitudes towards food and weight related beliefs, this study investigated new factors and complements existing research.

Among the general attitudes, parental dieting attitudes are most strongly and positively associated with the zBMI. At first glance, this result seems counter-intuitive; it is, however, plausible in light of evidence with respect to the concept of "restraint eating". People practicing restrained eating are characterized by frequent dieting, frequent over-eating and body dissatisfaction (Herman \& Mack, 1975; Herman \& Polivy, 1975). Though it is less clear whether restraint eating is a cause or a consequence of elevated body weight (Forrester-Knauss, Perren, \& Alsaker, 2012; Snoek, Engels, van Strien, \& Otten, 2013), there is strong evidence that restraint eating is associated with higher weight status in adults and adolescents (Braet et al., 2008; Braet \& Wydhooge, 2000; Mulvihill, Davies, \& Rogers, 2002; Munsch et al., 2007; Snoek, van Strien, Janssens, \& Engels, 2007; Soo, Shariff, Taib, \& Abu, 2008; Vissers et al., 2008) and must be considered as an unsuccessful weight management strategy. Also, research showed that children's restraint eating is similar to their parents' restraint eating (Elfhag, Tynelius, \& Rasmussen, 2010; Rutters et al., 2008; Snoek, van Strien, Janssens, \& Engels, 2009). There is a continuing debate on the mechanisms leading to higher weight in restrained eaters, assuming that in phases of overeating, caloric intake is elevated and surpasses potentially lost weight during dieting (Heatherton, Herman, Polivy, King, \& McGree, 1988; Stroebe, Mensink, Aarts, Schut, \& Kruglanski, 2008) or that, in spite of restraint eating, the caloric intake is not sufficiently reduced to achieve weight reduction (Stice, Cooper, Schoeller, Tappe, \& Lowe, 2007; Stice, Fisher, \& Lowe, 2004; T. van Strien, 1997; van Strien, Herman, Engels, Larsena, \& van Leeuwe, 2007). We did not investigate whether parents actually qualify as restraint eaters. However, our results are in line with these findings and show that even parents' simple positive attitude towards dieting is not associated with lower weight in children, but rather, with increased weight.

Our outcomes are also in line with the literature demonstrating that restrictive feeding practices are associated with higher child weight status (Clark et al., 2007; Faith et al., 2004; Sleddens et al., 2011). Restriction though could not add any explanatory power to our study, given that parents' dieting attitudes were considered. Again, for the weight-enhancing effect of restriction, the causal mechanisms are not clear, assuming for instance, deficits in the awareness of hunger and satiety and, therefore, related difficulties in regulation of food intake or deficits in self-regulation in the absence of parental control (Clark et al., 2007). A positive dieting attitude by parents might be operating in the same way as parents' restraint eating and restrictive feeding practices.

Our findings indicate that a positive attitude towards cooking and a lower identification with the way of eating are associated with higher weight status. More research is needed to investigate how these attitudes relate to actual caloric intake and subsequently to weight status. The question arises as to whether these two factors go along with a specific way of eating and potentially lead to the consumption of foods with higher calorie density or more food. However, it also needs to be acknowledged that the association between the zBMI and these factors is relatively weak. Thus, more research is also needed to replicate these findings in other cohorts.

With respect to the parents' beliefs concerning overweight, our results showed that self-efficacy for exercising and perceived benefits of healthy eating were negatively related to weight status, with self-efficacy for exercising being more strongly associated. This result supports findings that have identified parent self-efficacy as an important factor of adolescents' overweight. The concept of self-efficacy was developed by Bandura and is understood as the confidence in being able to perform the behavior in question and to overcome barriers that might hinder this behavior (Bandura, 1977). This confidence is built on experience and learning and is a major motivational force for social action; those with higher confidence are more motivated to perform the respective behaviors and work harder to overcome barriers (Bandura, 2001; Schwarzer, 2001). Though self-efficacy has been tested with respect to exercising and eating behavior extensively, it has only recently been recognized as an important parental factor that should be studied in the context of childhood obesity. It was examined with respect to exercise and found to be positively correlated with the physical activity of girls (Adkins et al., 2004) and with organized physical activity of younger and older children and non-organized activity of older children (Smith et al., 2010). Both studies did not investigate the association of parents' self-efficacy with the children's BMI. Another study considered parental self-efficacy with respect to physical activity, limiting screen time and change of eating patterns and found that overweight or obese parents and less educated parents had lower self-efficacy. Further, longer screen time, more fast food and sweetened beverage consumption was related to lower parent 
self-efficacy. Yet, there was no systematic association with the children's BMI (Taveras et al., 2009). Our study shows that indeed parents' self-efficacy is related to the children's weight status and therefore underlines the relevance of this concept. It also points to the fact that parents need support to manage their children's weight related behavior.

Recently, a scale was proposed to measure parental self-efficacy (Gerards et al., 2013; Nelson \& Davis, 2013) in line with Bandura's guidelines (Bandura, 2006) in order to capture self-efficacy with respect to different types of weight related behavior. Our approach to measuring self-efficacy was comparable with this. We considered both parents' self-efficacy to motivate their children to exercise and to eat healthily. However, parents' self-efficacy with regard to healthy eating was not associated with the children's weight status in our study. Yet, the response efficacy, i.e. perceived benefit of healthy eating, was associated with zBMI. In light of the counterproductive effect of trying to restrict caloric intake, e.g. with the purchase of "dieting products", this result indicates that parents of heavier children might profit from better education about what to eat, especially with respect to fruits and vegetables, in order to offer alternative strategies to reduce caloric intake. To the best of our knowledge, there was only one previous study that investigated the perceived benefit (response efficacy) of parents with respect to healthy eating, which was found to be linked to parents' tracking their children's eating behavior (Andrews, Silk, \& Eneli, 2010). The perceived benefit of exercising was not associated with the zBMI in our study. Future research needs to clarify how the different potential social cognitive determinants of parental behavior are interrelated and linked to children's weight related behavior and weight status.

In accordance with previous research, we found that a substantial portion of parents of overweight or obese children did not classify their child to be in the "correct" weight category. However, the parents' misperception of overweight or obese children, although frequent, does not seem to go along with differences in weight-related social cognitions or food-related attitudes. No significant differences could be observed among parents who misperceive the weight status and those who correctly perceive the weight status of their child. However, the absence of significance of such differences might be due to the limited number of observations, as only 174 out of the total 842 dyads were available to answer this research question. Though often assumed, it was rarely investigated whether misperception of children's weight status actually had an impact on relevant weight related behaviors and attitudes, with most research focusing on socio-demographic differences (Francescatto, Santos, Coutinho, \& Costa, 2014; Rietmeijer-Mentink, Paulis, van Middelkoop, Bindels, \& van der Wouden, 2013; Tompkins, Seablom, \& Brock, 2014; Towns \& D'Auria, 2009). In accordance with our results, a previous study, which examined social cognitive differences between parents who correctly and incorrectly classified their children's overweight, found comparable attitudes towards risk and knowledge with respect to healthy eating in both groups (Etelson et al., 2003). Also, in further support of our results, a longitudinal study demonstrated that the underestimation of children's overweight at the age of 5 did not parallel a higher zBMI at the age of 9 . To the contrary, the authors found that children who were correctly perceived as overweight at the age of 5 had a higher zBMI at the age of 9 (Gerards et al., 2014). More research is needed to investigate whether in other and larger samples of overweight or obese adolescents, systematic differences with respect to social cognitive variables among parents can be found. However, the evidence available until now indicates that this misperception has no practical implications for parental behaviors with respect to their children's weight management.

It is the strength of this study to have analyzed variables that have been less studied thus far but nevertheless seem to be relevant in the understanding of childhood overweight and obesity. Furthermore, this is a non-clinical sample also including normal weight adolescents, which provides a high ecological validity. Several limitations however, need to be taken into account when interpreting the results: Parents were invited only through written materials to participate. The refusal rate of $45 \%$ is not unusually high compared to other health related surveys (Moghaddam \& Mousavi, 2009; Shannon \& Bradshaw, 2002) and we did not find a substantial bias with respect to the outcome of interest or socio-economic status. Nevertheless, we cannot exclude biases due to the limited response rate. Further, for some of the analyzed variables, reliability was not sufficiently high, which forced us to use only one questionnaire item to cover the concept of interest. Although this allows a clear interpretation of the variable, we cannot exclude that the measurement could be biased. Furthermore, only self-reported measures could be used to calculate the parents' BMI and finally the cross-sectional character of the study does not allow the drawing of any causal conclusions.

\section{Conclusion}

Our results indicate that parents' lack of successful weight management strategies is more clearly associated with their children's weight status than with a lack of problem awareness. Current dieting attempts especially need to be replaced with more successful strategies. The lack of strategies to overcome barriers that hinder adolescents to 
be more physically active needs to be addressed as well. This means that parents need support to enhance their capacity and confidence (self-efficacy) to motivate their children to exercise more.

\section{Acknowledgement}

The project was funded by the German Ministry of Education and Science.

\section{References}

Adkins, S., Sherwood, N. E., Story, M., \& Davis, M. (2004). Physical activity among African-American girls: the role of parents and the home environment. Obesity Research, 12 Suppl, 38S-45S. http://dx.doi.org/10.1038/oby.2004.267

Aljunaibi, A., Abdulle, A., \& Nagelkerke, N. (2013). Parental Weight Perceptions: A Cause for Concern in the Prevention and Management of Childhood Obesity in the United Arab Emirates. PLoS ONE, 8(3). http://dx.doi.org/10.1371/journal.pone.0059923

Andrews, K. R., Silk, K. S., \& Eneli, I. U. (2010). Parents as health promoters: A theory of planned behavior perspective on the prevention of childhood obesity. Journal of Health Communication, 15(1), 95-107. http://dx.doi.org/10.1080/10810730903460567

Bandura, A. (1977). Self-efficacy: Toward a Unifying Theory of Behavioral Change. Psychological Review, 84(2), 191-215. http://dx.doi.org/10.1037/0033-295X.84.2.191

Bandura, A. (2001). SOCIAL COGNITIVE THEORY: An Agentic Perspective. Annu. Rev. Psychol, 52, 1-26. http://dx.doi.org/10.1146/annurev.psych.52.1.1

Bandura, A. (2006). Guide for constructing self-efficacy scales. In F. Pajares \& T. Urdan (Eds.), Self-Efficacy Beliefs of Adolescents (pp. 307-337). Greenwich: Information Age Publishing.

Bebetsos, E., Chroni, S., \& Theodorakis, Y. (2002). Physically active students' intentions and self-efficacy towards healthy eating. Psychological Reports, 91(2), 485-495. http://dx.doi.org/10.2466/pr0.2002.91.2.485

Becker, M. H., Maiman, L. A., Kirscht, J. P., Haefner, D. P., \& Drachman, R. H. (1977). The health belief model and prediction of dietary compliance: A field experiment. Journal of Health and Social Behavior, 18(4), 348-366. http://dx.doi.org/10.2307/2955344

Berge, J. M., Jin, S. W., Hannan, P., \& Neumark-Sztainer, D. (2013). Structural and interpersonal characteristics of family meals: Associations with adolescent body mass index and dietary patterns. Journal of the Academy of Nutrition and Dietetics, 113(6), 816-822. http://dx.doi.org/10.1016/j.jand.2013.02.004

Bisogni, C. A., Connors, M., Devine, C. M., \& Sobal, J. (2002). Who we are and how we eat: A qualitative study of identities in food choice. Journal of Nutrition Education and Behavior, 34(3), 128-139. http://dx.doi.org/10.1016/S1499-4046(06)60082-1

Braet, C., Claus, L., Goossens, L., Moens, E., Van Vlierberghe, L., \& Soetens, B. (2008). Differences in eating style between overweight and normal-weight youngsters. Journal of Health Psychology, 13(6), 733-743. http://dx.doi.org/10.1177/1359105308093850

Braet, C., \& Wydhooge, K. (2000). Dietary restraint in normal weight and overweight children. A cross-sectional study. International journal of obesity and related metabolic disorders: journal of the International Association for the Study of Obesity, 24(3), 314-318. http://dx.doi.org/10.1038/sj.ijo.0801129

Brickenkamp, R. (1997). Handbuch psychologischer und pädagogischer Tests (2nd ed.). Göttingen (u.a.): Hogrefe.

Clark, H. R., Goyder, E., Bissell, P., Blank, L., \& Peters, J. (2007). How do parents' child-feeding behaviours influence child weight? Implications for childhood obesity policy. Journal of Public Health, 29(2), 132-141. http://dx.doi.org/10.1093/pubmed/fdm012

Cole, T. J., Bellizzi, M. C., Flegal, K. M., Dietz, W. H. (2000). Establishing a standard definition for child overweight and obesity worldwide: international survey. BMJ, 320(7244), 1240. http://www.ncbi.nlm.nih.gov/pmc/articles/PMC27365/

Conner, M., Norman, P., \& Bell, R. (2002). The theory of planned behavior and healthy eating. Health Psychology, 21(2), 194-201. http://dx.doi.org/10.1037/0278-6133.21.2.194

Daniels, S. R., Arnett, D. K., Eckel, R. H., Gidding, S. S., Hayman, L. L., Kumanyika, S., ... Williams, C. L. (2005). Overweight in children and adolescents: Pathophysiology, consequences, prevention, and treatment. Circulation, 111(15), 1999-2012. http://dx.doi.org/10.1161/01.CIR.0000161369.71722.10 
De La O, A., Jordan, K. C., Ortiz, K., Moyer-Mileur, L. J., Stoddard, G., Friedrichs, M., . . Mihalopoulos, N. L. (2009). Do Parents Accurately Perceive Their Child's Weight Status? Journal of Pediatric Health Care, 23(4), 216-221. http://dx.doi.org/10.1016/j.pedhc.2007.12.014

Devine, C. M., Sobal, J., Bisogni, C. A., \& Connors, M. (1999). Food choices in three ethnic groups: interactions of ideals, identities and roles. Journal of Nutrition Education, 31(2), 86-93. http://dx.doi.org/10.1016/S0022-3182(99)70400-0

Eckstein, K. C., Mikhail, L. M., Ariza, A. J., Thomson, J. S., Millard, S. C., Binns, H. J., \& Group, f. t. P. P. R. (2006). Parents' Perceptions of Their Child's Weight and Health. Pediatrics, 117(3), 681-690. http://dx.doi.org/10.1542/peds.2005-0910

Elfhag, K., Tynelius, P., \& Rasmussen, F. (2010). Family links of eating behaviour in normal weight and overweight children. International Journal of Pediatric Obesity, 5(6), 491-500. http://dx.doi.org/10.3109/17477160903497001

Epstein, L. H., Valoski, A., Wing, R. R., \& McCurley, J. (1994). Ten-Year Outcomes of Behavioral Family-Based Treatment for Childhood Obesity. Health Psychology, 13(5), 373-383. http://dx.doi.org/10.1037/0278-6133.13.5.373

Etelson, D., Brand, D. A., Patrick, P. A., \& Shirali, A. (2003). Childhood obesity: Do parents recognize this health risk? Obesity Research, 11(11), 1362-1368. http://dx.doi.org/10.1038/oby.2003.184

Faith, M. S., Scanlon, K. S., Birch, L. L., Francis, L. A., \& Sherry, B. (2004). Parent-child feeding strategies and their relationships to child eating and weight status. Obesity Research, 12(11), 1711-1722. http://dx.doi.org/10.1038/oby.2004.212

Fila, S. A., \& Smith, C. (2006). Applying the Theory of Planned Behavior to healthy eating behaviors in urban Native American youth. International Journal of Behavioral Nutrition and Physical Activity, 3. http://dx.doi.org/10.1186/1479-5868-3-11

Fisher, J. O., \& Birch, L. L. (1999). Restricting access to palatable foods affects children's behavioral response, food selection, and intake. The American Journal of Clinical Nutrition, 69(6), 1264-1272.

Forrester-Knauss, C., Perren, S., \& Alsaker, F. D. (2012). Does body mass index in childhood predict restraint eating in early adolescence? Appetite, 59(3), 921-926. http://dx.doi.org/10.1016/j.appet.2012.08.026

Francescatto, C., Santos, N. S., Coutinho, V. F., \& Costa, R. F. (2014). Mothers' perceptions about the nutritional status of their overweight children: a systematic review. Jornal de Pediatria. http://dx.doi.org/10.1016/j.jped.2014.01.009

Fruh, S. M., Fulkerson, J. A., Mulekar, M. S., Kendrick, L. A. J., \& Clanton, C. (2011). The Surprising Benefits of the Family Meal. Journal for Nurse Practitioners, 7(1), 18-22. http://dx.doi.org/10.1016/j.nurpra.2010.04.017

Ganzeboom, H. B. G., De Graaf, P. M., \& Treiman, D. J. (1992). A standard international socio-economic index of occupational status. Social Science Research, 21(1), 1-56. http://dx.doi.org/10.1016/0049-089X(92)90017-B

Ganzeboom, H. B. G., \& Treiman, D. J. (1996). Internationally comparable measures of occupational status for the 1988 International Standard Classification of Occupations. Social Science Research, 25(3), 201-239. http://dx.doi.org/10.1006/ssre.1996.0010

Ganzeboom, H. B. G., \& Treiman, D. J. (2003). Advances in Cross-National Comparison. In J. Hoffmeyer-Zlotnik \& C. Wolf (Eds.), Three internationally standardised measures for comparative research on occupational status (pp. 159-175). Kluwer Academic/Plenum Publishers. http://dx.doi.org/10.1007/978-1-4419-9186-7_9

Geis, A. (2007). Handbuch für die Berufsvercodung. Mannheim: Zentrum für Umfragen, Methoden und Analysen (ZUMA).

Gerards, S. M. P. L., Gubbels, J. S., Dagnelie, P. C., Kremers, S. P. J., Stafleu, A., De Vries, N. K., \& Thijs, C. (2014). Parental perception of child's weight status and subsequent BMIz change: The KOALA birth cohort study. Bmc Public Health, 14(1). http://dx.doi.org/10.1186/1471-2458-14-291

Gerards, S. M. P. L., Hummel, K., Dagnelie, P. C., de Vries, N. K., \& Kremers, S. P. J. (2013). Parental self-efficacy in childhood overweight: Validation of the Lifestyle Behavior Checklist in the Netherlands. 
International Journal of Behavioral Nutrition and Physical Activity, 10. http://dx.doi.org/10.1186/1479-5868-10-7

Golan, M. (2006). Parents as agents of change in childhood obesity - From research to practice. International Journal of Pediatric Obesity, 1(2), 66-76. http://dx.doi.org/10.1080/17477160600644272

Golan, M., \& Crow, S. (2004). Targeting Parents Exclusively in the Treatment of Childhood Obesity: Long-Term Results. Obesity Research, 12 (2), 357-361. http://dx.doi.org/10.1038/oby.2004.45

Grunert, K. G. (2002). Current issues in the understanding of consumer food choice. Trends in Food Science \& Technology, 13, 275-285. http://dx.doi.org/10.1016/S0924-2244(02)00137-1

Guidetti, M., Conner, M., Prestwich, A., \& Cavazza, N. (2012). The transmission of attitudes towards food: Twofold specificity of similarities with parents and friends. British Journal of Health Psychology, 17(2), 346-361. http://dx.doi.org/10.1111/j.2044-8287.2011.02041.x

Hausenblas, H. A., Carron, A. V., \& Mack, D. E. (1997). Application of the theories of reasoned action and planned behavior to exercise behavior: A meta-analysis. Journal of Sport and Exercise Psychology, 19(1), 36-51.

Hayn, D., \& Schultz, I. (2004). Ernährung und Lebensstile in der sozial-ökologischen Forschung - Einsichten in die motivationalen Hintergründe des alltäglichen Ernährungshandelns. In BfN (Ed.), Ernährungskultur: Land(wirt)schaft, Ernährung und Gesellschaft. 26. Wissenschaftliche Jahrestagung der AGEV (pp. 1-11).

Heatherton, T. F., Herman, C. P., Polivy, J., King, G. A., \& McGree, S. T. (1988). The (Mis)measurement of Restraint: An Analysis of Conceptual and Psychometric Issues. Journal of Abnormal Psychology, 97(1), 19-28. http://dx.doi.org/10.1037/0021-843X.97.1.19

Herman, C. P., \& Mack, D. (1975). Restrained and unrestrained eating. Journal of Personality, 43(4), $647-660$. http://dx.doi.org/10.1111/j.1467-6494.1975.tb00727.x

Herman, C. P., \& Polivy, J. (1975). Anxiety, Restraint, and Eating Behavior. Journal of Abnormal Psychology, 84(6), 666-672. http://dx.doi.org/10.1037/0021-843X.84.6.666

Hewitt, A. M., \& Stephens, C. (2007). Healthy eating among 10-13-year-old New Zealand children: Understanding choice using the Theory of Planned Behaviour and the role of parental influence. Psychology, Health and Medicine, 12(5), 526-535. http://dx.doi.org/10.1080/13548500601164396

Hoffmeyer-Zlotnik, J. H. P., \& Geis, A. (2003). Berufsklassifikation und Messung des beruflichen Status/Prestige. ZUMA-Nachrichten, 52, 125-138.

Hudson, E., McGloin, A., \& McConnon, A. (2012). Parental weight (mis)perceptions: Factors influencing parents' ability to correctly categorise their child's weight status. Maternal and Child Health Journal, 16(9), 1801-1809. http://dx.doi.org/10.1007/s10995-011-0927-1

Janz, N. K., \& Becker, M. H. (1984). The Health Belief Model: a decade later. Health Education Quarterly, 11(1), 1-47. http://dx.doi.org/10.1177/109019818401100101

Kaufman, F. R. (2002). Type 2 diabetes mellitus in children and youth: A new epidemic. Journal of Pediatric Endocrinology and Metabolism, 15(SUPPL. 2), 737-744. http://dx.doi.org/10.1515/JPEM.2002.15.S2.737

Kromeyer-Hauschild, K., Wabitsch, M., Kunze, D., Geller, F., Geiß, H. C., Hesse, V., ... Hebebrand, J. (2001). Perzentile für den Body-mass-Index für das Kindes- und Jugendalter unter Heranziehung verschiedener deutscher Stichproben. Monatsschreiben $\quad$ Kinderheilkunde, $149, \quad$ 807-818. http://dx.doi.org/10.1007/s001120170107

Krömker, D., \& Vogler, J. (2011). Übergewicht und Adipositas - Eine Diätgeschichte. Ergebnisse einer bundesweiten Befragungsstudie mit Kindern und Jugendlichen aus psycho-sozialer Sicht. In M. Zwick, J. Deuschle \& O. Renn (Eds.), Übergewicht und Adipositas bei Kindern und Jugendlichen (pp. 115-136). Wiesbaden: VS-Verlag. http://dx.doi.org/10.1007/978-3-531-93158-6_7

Larson, N. I., Neumark-Sztainer, D., Hannan, P. J., \& Story, M. (2007). Family Meals during Adolescence Are Associated with Higher Diet Quality and Healthful Meal Patterns during Young Adulthood. Journal of the American Dietetic Association, 107(9), 1502-1510. http://dx.doi.org/10.1016/j.jada.2007.06.012

Lim, H., \& Wang, Y. (2013). Body weight misperception patterns and their association with health-related factors among adolescents in South Korea. Obesity, 21(12), 2596-2603. http://dx.doi.org/10.1002/oby.20361 
Lindeman, M., \& Sirelius, M. (2001). Food choice ideologies: The modern manifestations of normative and humanist views of the world. Appetite, 37(3), 175-184. http://dx.doi.org/10.1006/appe.2001.0437

Lloyd, A. B., Lubans, D. R., Plotnikoff, R. C., Collins, C. E., \& Morgan, P. J. (2014). Maternal and paternal parenting practices and their influence on children's adiposity, screen-time, diet and physical activity. Appetite, 79, 149-157. http://dx.doi.org/10.1016/j.appet.2014.04.010

Lowe, M. R. (2003). Self-Regulation of Energy Intake in the Prevention and Treatment of Obesity: Is It Feasible? Obesity Research, 11 (Suppl. October), 44S-59S.

Lundahl, A., Kidwell, K. M., \& Nelson, T. D. (2014). Parental underestimates of child weight: A meta-analysis. Pediatrics, 133(3), e689-e703. http://dx.doi.org/10.1542/peds.2013-2690

Moghaddam, M. F., \& Mousavi, A. (2009). Prediction and control of response rate to surveys. American Journal of Mathematical and Management Sciences, 29(3-4), 337-370. http://dx.doi.org/10.1080/01966324.2009.10737763

Müller, C., Roscher, K., Parlesak, A., \& Bode, C. (2011). Systemische Risikofaktoren relativieren den alleinigen Einfluss von Ernährung und Bewegung bei der Entstehung von Übergewicht und Adipositas bei Kindern und Jugendlichen. In M. Zwick, J. Deuschle \& O. Renn (Eds.), Übergewicht und Adipositas bei Kindern und Jugendlichen (pp. 91-114). Wiesbaden: VS-Verlag. http://dx.doi.org/10.1007/978-3-531-93158-6_6

Mulvihill, C. B., Davies, G. J., \& Rogers, P. J. (2002). Dietary restraint in relation to nutrient intake, physical activity and iron status in adolescent females. Journal of human nutrition and dietetics: the official journal of the British Dietetic Association, 15(1), 19-31.

Munsch, S., Hasenboehler, K., Michael, T., Meyer, A. H., Roth, B., Biedert, E., \& Margraf, J. (2007). Restrained eating in overweight children: Does eating style run in families? International journal of pediatric obesity: IJPO: An official journal of the International Association for the Study of Obesity, 2(2), 97-103.

Nelson, M., \& Davis, M. C. (2013). Development and preliminary validation of the Parent Efficacy for Child Healthy Weight Behaviour Scale. Journal of Health Psychology, 18(2), 282-291. http://dx.doi.org/10.1177/1359105312439732

O'Connell, J. K., Price, J. H., Roberts, S. M., Jurs, S. G., \& McKinley, R. (1985). Utilizing the health belief model to predict dieting and exercising behavior of obese and nonobese adolescents. Health Education Quarterly, 12(4), 343-351. http://dx.doi.org/10.1177/109019818501200401

Ogden, C. L., Yanovski, S. Z., Carroll, M. D., \& Flegal, K. M. (2007). The Epidemiology of Obesity. Gastroenterology, 132(6), 2087-2102. http://dx.doi.org/10.1053/j.gastro.2007.03.052

Park, D. Y. (2011). Utilizing the health belief model to predicting female middle school students' behavioral intention of weight reduction by weight status. Nutrition Research and Practice, 5(4), 337-348. http://dx.doi.org/10.4162/nrp.2011.5.4.337

Plotnikoff, R. C., Costigan, S. A., Karunamuni, N., \& Lubans, D. R. (2013). Social cognitive theories used to explain physical activity behavior in adolescents: A systematic review and meta-analysis. Preventive Medicine, 56(5), 245-253. http://dx.doi.org/10.1016/j.ypmed.2013.01.013

Rietmeijer-Mentink, M., Paulis, W. D., van Middelkoop, M., Bindels, P. J., \& van der Wouden, J. C. (2013). Difference between parental perception and actual weight status of children: A systematic review. Maternal and Child Nutrition, 9(1), 3-22. http://dx.doi.org/10.1111/j.1740-8709.2012.00462.x

Roos, E., Lehto, R., \& Ray, C. (2012). Parental family food choice motives and children's food intake. Food Quality and Preference, 24(1), 85-91. http://dx.doi.org/10.1016/j.foodqual.2011.09.006

Rutters, F., Nieuwenhuizen, A. G., Vogels, N., Bouwman, F., Mariman, E., \& Westerterp-Plantenga, M. S. (2008). Leptin-adiposity relationship changes, plus behavioral and parental factors, are involved in the development of body weight in a Dutch children cohort. Physiology and Behavior, 93(4-5), 967-974. http://dx.doi.org/10.1016/j.physbeh.2007.12.021

Sallis, J. F., Prochaska, J. J., \& Taylor, W. C. (2000). A review of correlates of physical activity of children and adolescents. Medicine and Science in Sports and Exercise, 32(5), 963-975. http://dx.doi.org/10.1097/00005768-200005000-00014

Schwarzer, R. (2001). Social-Cognitive Factors in Changing Health-Related Behaviors. Current Directions in Psychological Science, 10(2), 47-51. http://dx.doi.org/10.1111/1467-8721.00112 
Shannon, D. M., \& Bradshaw, C. C. (2002). A comparison of response rate, response time, and costs of mail and electronic surveys. Journal of Experimental Education, 70(2), 179-192. http://dx.doi.org/10.1080/00220970209599505

Sleddens, E. F. C., Gerards, S. M. P. L., Thijs, C., De Vries, N. K., \& Kremers, S. P. J. (2011). General parenting, childhood overweight and obesity-inducing behaviors: A review. International Journal of Pediatric Obesity, $6(2-2)$, e12-e27.

Smith, B., Grunseit, A., Hardy, L., King, L., Wolfenden, L., \& Milat, A. (2010). Parental influences on child physical activity and screen viewing time: a population based study. Bmc Public Health, 10(1), 593. http://dx.doi.org/10.1186/1471-2458-10-593

Snoek, H. M., Engels, R. C. M. E., van Strien, T., \& Otten, R. (2013). Emotional, external and restrained eating behaviour and BMI trajectories in adolescence. Appetite, 67, 81-87. http://dx.doi.org/10.1016/j.appet.2013.03.014

Snoek, H. M., van Strien, T., Janssens, J. M., \& Engels, R. C. (2007). Emotional, external, restrained eating and overweight in Dutch adolescents. The Scandinavian journal of psychology, 48(1), 23-32. http://dx.doi.org/10.1111/j.1467-9450.2006.00568.x

Snoek, H. M., van Strien, T., Janssens, J. M. A. M., \& Engels, R. C. M. E. (2009). Longitudinal relationships between fathers', mothers', and adolescents' restrained eating. Appetite, 52(2), 461-468. http://dx.doi.org/10.1016/j.appet.2008.12.009

Soo, K. L., Shariff, Z. M., Taib, M. N. M., \& Abu, B. S. (2008). Eating behaviour, body image, and self-esteem of adolescent girls in Malaysia. Perceptual and Motor Skills, 106(3), 833-844. http://dx.doi.org/10.2466/pms.106.3.833-844

Steptoe, A., Pollard, T. M., \& Wardle, J. (1995). Development of a Measure of the Motives Underlying the Selection of Food: the Food Choice Questionnaire. Appetite, 25, 267-284. http://dx.doi.org/10.1006/appe.1995.0061

Stice, E., Cooper, J. A., Schoeller, D. A., Tappe, K., \& Lowe, M. R. (2007). Are Dietary Restraint Scales Valid Measures of Moderate- to Long-Term Dietary Restriction? Objective Biological and Behavioral Data Suggest Not. Psychological Assessment, 19(4), 449-458. http://dx.doi.org/10.1037/1040-3590.19.4.449

Stice, E., Fisher, M., \& Lowe, M. R. (2004). Are Dietary Restraint Scales Valid Measures of Acute Dietary Restriction? Unobtrusive Observational Data Suggest Not. Psychological Assessment, 16, 51-59. http://dx.doi.org/10.1037/1040-3590.16.1.51

Stroebe, W., Mensink, W., Aarts, H., Schut, H., \& Kruglanski, A. W. (2008). Why dieters fail: Testing the goal conflict model of eating. Journal of Experimental Social Psychology, 44(1), 26-36. http://dx.doi.org/10.1016/j.jesp.2007.01.005

Sullivan, K. A., White, K. M., Young, R. M., Chang, A., Roos, C., \& Scott, C. (2008). Predictors of Intention to Reduce Stroke Risk Among People at Risk of Stroke: An Application of an Extended Health Belief Model. Rehabilitation Psychology, 53(4), 505-512. http://dx.doi.org/10.1037/a0013359

Tabachnik, B., \& Fidell, L. (2001). Using multivariate statistics. Boston: Allyn and Bacon.

Taveras, E. M., Mitchell, K., \& Gortmaker, S. L. (2009). Parental confidence in making overweight-related behavior changes. Pediatrics, 124(1), 151-158. http://dx.doi.org/10.1542/peds.2008-2892

Tompkins, C. L., Seablom, M., \& Brock, D. W. (2014). Parental Perception of Child's Body Weight: A Systematic Review. Journal of Child and Family Studies. http://dx.doi.org/10.1007/s10826-014-9945-0

Towns, N., \& D'Auria, J. (2009). Parental Perceptions of Their Child's Overweight: An Integrative Review of the Literature. Journal of Pediatric Nursing, 24(2), 115-130. http://dx.doi.org/10.1016/j.pedn.2008.02.032

van Strien, T. (1997). Are Most Dieters Unsuccessful? An Alternative Interpretation of the Confounding of Success and Failure in the Measurement of Restraint. European Journal of Psychological Assessment, 13(3), 186-194. http://dx.doi.org/10.1027/1015-5759.13.3.186

van Strien, T., Herman, P. C., Engels, R. C. M. E., Larsena, J. K., \& van Leeuwe, Jan F.J. . (2007). Construct validation of the Restraint Scale in normal-weight and overweight females. Appetite, 49 109-121. http://dx.doi.org/10.1016/j.appet.2007.01.003 
Vissers, D., Devoogdt, N., Gebruers, N., Mertens, I., Truijen, S., \& Van Gaal, L. (2008). Overweight in Adolescents: Differences per Type of Education. Does One Size Fit All? Journal of Nutrition Education and Behavior, 40(2), 65-71. http://dx.doi.org/10.1016/j.jneb.2007.06.010

Wansink, B., \& Van Kleef, E. (2014). Dinner rituals that correlate with child and adult BMI. Obesity, 22(5), E91-E95. http://dx.doi.org/10.1002/oby.20629

WHO. (2012). Population-based approaches to childhood obesity prevention In WHO (Ed.). Geneva, Switzerland: WHO.

\section{Copyrights}

Copyright for this article is retained by the author(s), with first publication rights granted to the journal.

This is an open-access article distributed under the terms and conditions of the Creative Commons Attribution license (http://creativecommons.org/licenses/by/3.0/). 